\title{
MIR196A2 wt Allele
}

National Cancer Institute

\section{Source}

National Cancer Institute. MIR196A2 wt Allele. NCI Thesaurus. Code C82211.

The human MIR196A2 wild-type allele is located in the vicinity of $12 q 13.13$ and is approximately 109 bases in length. This allele, which encodes MIR196A2 pre-miRNA, plays a role in the regulation of gene expression. Alteration in the expression of this gene is associated with development of esophageal cancer. 